\title{
Effects of Chemically Pretreated Bovine Serum Samples on Sensitivity of Rose Bengal Test for Serodiagnosis of Bovine Brucellosis
}

\author{
Lamees A. El-Tantawy ${ }^{1}$, Lubna, F. Farahat ${ }^{\text {* }}$, Eman S. Ramadan ${ }^{2}$, and Fatma F. Warda ${ }^{3}$ \\ ${ }^{1}$ Department of Antigens and Serums, Veterinary Serum and Vaccine Research Institute, Agriculture Research \\ Center (ARC),Egypt. ${ }^{2}$ Animal Reproductive Disease Department, Animal Reproduction Research Institute, \\ Agriculture Research Center (ARC),Egypt. \\ ${ }^{3}$ Department of Equine Vaccine Research, Veterinary Serum and Vaccine Research Institute, Agriculture \\ Research Center (ARC),Egypt. \\ *Corresponding authors: Lubna, F. Farahat; E-mail: lubnafady@gmail.com
}

\begin{abstract}
The standard serological test such as Rose Bengal Plate Test (RBPT) is routinely used for the diagnosis of brucellosis. This test depends on the agglutination of colored particulate antigen (killed Brucella organisms) by the antibodies present in sera of infected animals. Faulty negative and positive results are commonly experienced in these traditional agglutination tests. We developed three simple, new, additional and cost-effective steps that can help in these problems; Superagglutination test for serodiagnosis of brucellosis differs from conventional RBPT by three simple new and coast effective additional steps which are used to overcome this problem. These steps depend on the staining of sera antibodies by adding dye before the test and addition of diluted biotinylated antiglobulin and Avidin in sequence then mixing the antigen with the stained serum. By testing 150 serum samples, Superagglutination test had higher positive predictive value and specificity than RBPT and standard tube agglutination test (STAT). Also, it had higher negative predictive value and sensitivity than RBPT, STAT, ELISA (Indirect enzyme-linked immunosorbent assay) and CFT (Complement Fixation test).
\end{abstract}

Original Article:

DOI:https://dx.doi.org/10.21608/javs.2020.8 $\underline{5550}$

Received :20 Jan., 2020

Accepted: 25 Feb., 2020

Published in April 2020

This is an open access article under the term of the Creative Commons Attribution 4.0 (CC-BY) Internationa] License. To view a copy of this license visit

http://creativecommons.org/licenses/by/ $\underline{4.0 /}$

\section{J. Appl. Vet. Sci., 5(2 ): 6-12.}

Keywords: Brucella, CFT, ELISA, RBPT, STAT.

\section{INTRODUCTION}

Brucellosis is an important worldwide zoonotic bacterial disease caused by Brucella species and affecting different mammals including man, sheep, goats, cattle, swine, marine mammals and rodents. The disease mainly affects the reproductive system with significant loss of productivity and re-productivity of affected animals. Control of brucellosis depends mainly on comprehensive vaccination, surveillance and quarantine programs. Both control and prevention procedures are highly depending on accurate diagnostic tools and effective and safe vaccination programs (WHO, 2006).

The RBPT is a pilot, cheap, rapid and effective screening test for Brucella diagnosis. It can be performed with minimum facilities. Because of its apparent simplicity, high level of standardization of antigen but the accuracy of the reading is needed
(Malek et al., 2013). However, it may give false negative and positive results. Many factors affect its reaction and reading as some people can see the finer agglutination while many others cannot. Very low concentration of antibodies may not give visible agglutination. False-positive results may arise due to the inability to differentiate non-specific aggregates of antigen particles alone from the true agglutinates comprising both antigen and antibody. False-negative results may be due to a small clump size in sera with low titers of antibody. Prozoning may also lead to the false-negative reaction when sera of high antibody titers are tested.

So, to get an accurate diagnosis of Brucella infection, a combination of RBPT, ELISA and CFT should be used.This trial aimed to develop a new Super agglutination test with higher positive and negative predictive values and elevated specificity and sensitivity than traditional RBPT to give more accurate 
serodiagnosis without any change in simplicity and ease of test application and without increasing the cost of the test.

\section{MATERIALS AND METHODS}

\section{Brucella strains}

Strain-99 (S-99), smooth B.abortus biovar 1 (Weybridge, England) .

\section{Brucella antigens for serologic tests}

Conventional Rose Bengal and Tube Agglutination Antigens prepared from B.abortus (S-99) according to (Alton et al., 1988 and OIE, 2016).

\section{Serum samples}

A total of one hundred-fifty cow's serum samples were collected from different farms in different Egyptian governorates.

\section{Chemicals and Stains}

4.1. Rose Bengal stain (Sigma) used for staining of Brucella cells (B.abortus S.99) according to Alton et al. (1988).

4.2. Coomassie Blue Stain (Sigma) used for staining of protein used for staining of serum in Superagglutintion Test.

4.3. Biotinylated anti-bovine IgG (Sigma).

4.4. Streptavidin. (Sigma).

\section{Serologic tests}

\subsection{Conventional Rose Bengal Plate Test (RBPT)}

It was performed as described by Alton $\boldsymbol{e t}$ al. (1988), briefly, the sera and antigen were brought to room temperature before use. Equal volumes $(30 \mu \mathrm{l})$ of standardized $B$. abortus antigen Weybridge strain 99 and test serum were mixed thoroughly and rotated on a clean glass slide using a stick applicator, and the slide was rocked for 4 min. The formation of clear clumps was considered a positive test while the absence of clear clumps was considered a negative reaction.

\subsection{Standard Tube Agglutination test (STAT)}

It was performed, following the procedure described by Alton et al. (1988), a plain antigen of Brucella abortus(S-99) was used. Two-fold serial dilutions $(1: 20$ to $1: 640)$ of the sera were prepared in phenol saline and equal volume $(0.5 \mathrm{ml})$ of antigen was added to each tube. All the tubes were incubated at $37^{\circ} \mathrm{C}$ for $24 \mathrm{~h}$. The results were compared with the antigen control tube showing $50 \%$ agglutination. A titer of 1:40 or above was considered positive.

5.3. Superagglutintion Test (Modified Rose Bengal Plate Antigen (RBPA)

An equal volume $(2.5 \mu \mathrm{l})$ of RBPA colored antigens and stained tested sera were mixed with
$1 \mu 1$ of $0.1 \%$ Coomassie Blue dye, $1 \mu 1$ of biotinylated anti-bovine $\operatorname{IgG}$ and $1 \mu 1$ streptavidin, on a clean glass slide. The slide was observed for 4 minutes for the formation of clumps. Ordinary hand lens was used occasionally for better visibility. The slides were viewed under a low power (4xor 10X) objective lens under a microscope to confirm the clumping in case of doubt. Formation of clear clumps, within which presence of both blue colour and the pink colour together were considered as positive, while the absence of clear agglutinates or aggregates of pink color alone or blue-colored mass alone were considered as negative.

5.4. Indirect enzyme-linked immunosorbent assay (ELISA) (1988)

It was performed according to Alton et al.,

\section{Complement Fixation test (CFT)}

Which was performed on a microplate, following the procedure described by Alton $\boldsymbol{e t}$ al. (1988). Complement fixation at a dilution of $3 \log 2$ (1:8), the level recommended by the Australian Bureau of Animal Health, (1979) which was regarded as a positive reaction. Serum samples were titrated $1: 4$ to $1: 128$ in the CFT. Titers determined by CFT were expressed as $\log 2$ of the reciprocal of the last dilution at which a positive reaction occurred (Australian Bureau of Animal Health, 1979).

Considering CFT as a gold standard test (Yohannes et al., 2012) antigens sensitivity, relative sensitivity and specificity were calculated using (http://vassarstats.net/clin1.html) as shown in table (1).

Table 1: Calculation of sensitivity and specificity concerning gold standard test

\begin{tabular}{|c|c|c|c|c|}
\hline \multicolumn{2}{|c|}{} & \multicolumn{2}{c|}{$\begin{array}{c}\text { Gold Standard } \\
\text { Test (Cft) }\end{array}$} & \multirow{2}{*}{ Total } \\
\cline { 3 - 4 } & Positive & Negative & \\
\hline \multirow{2}{|c|}{$\begin{array}{c}\text { Test } \\
\begin{array}{c}\text { Under } \\
\text { Evaluation }\end{array}\end{array}$} & Positive & A & B & A+B \\
\cline { 2 - 5 } & Negative & C & D & C+D \\
\hline \multicolumn{2}{|c|}{ Total } & A+C & B+D & N (264) \\
\hline
\end{tabular}

RelativeSensitivity $=\mathrm{A} / \mathrm{A}+\mathrm{C}$

Specificity $=\mathrm{D} / \mathrm{D}+\mathrm{B}$

True positive (Positive Predictive Value $)=A / A+B$ False-positive $(\mathrm{B})=\mathrm{B} / \mathrm{A}+\mathrm{B}$

True negative (Negative Predictive Value) $=\mathrm{D} / \mathrm{D}+\mathrm{C}$ False-negative $(\mathrm{C})=\mathrm{C} / \mathrm{D}+\mathrm{C}$ 


\section{Effects of Chemically Pretreated Bovine Serum Samples on Sensitivity ......}

\section{RESULTS}

In the present study, 150 bovine sera samples were tested by RBPT, STAT, ELISA, Modified Rose Bengal Antigen Superagglutination test and CFT as shown in table(2). Results revealed that there are no satisfactory differences observed in the specificity of all used tests (Table3). Concerning CFT as a gold standard test, satisfactory differences were observed insensitivity of different tests used in this study. The sensitivity of RBT, STAT and ELISA were $24.66 \%$, $26.66 \%$ and $28 \%$, respectively, where the modified Rose Bengal test showed the highest sensitivity (31.33
$\%)$. Results of relative sensitivity showed a satisfactory difference between different tests with highest relative sensitivity in case of using Super-agglutination antigen $(95.92 \%)$ where the relative sensitivity of other tests were $75.51 \%, 81.63 \%$ and $85.71 \%$ using RBT, STAT and ELISA respectively (Table 3). Elevation in sensitivity is related to decrease in the number of falsenegative cases which were $4.08 \%, 24.49 \%, 18.37 \%$ and $14.29 \%$ in Modified Rose Bengal test (Superagglutination), RBT, STAT and ELISA respectively as shown in tables $(3,4)$.

Table 2: Numbers of positive and negative samples in each conducting test

\begin{tabular}{|c|c|c|c|c|c|c|c|c|c|c|}
\hline \multirow{2}{*}{$\begin{array}{c}\begin{array}{c}\text { Serological } \\
\text { test }\end{array} \\
\text { Result }\end{array}$} & \multicolumn{2}{|c|}{ RBPT } & \multicolumn{2}{|c|}{ STAT } & \multicolumn{2}{|c|}{ ELISA } & \multicolumn{2}{|c|}{$\begin{array}{c}\text { Superagglutinati } \\
\text { on test }\end{array}$} & \multicolumn{2}{|c|}{$\begin{array}{c}\text { CFT } \\
\text { Gold Standard } \\
\text { (CFT Test) }\end{array}$} \\
\hline & $(+\mathrm{ve}))$ & $(-v e)$ & $(+\mathrm{ve})$ & $(-v e)$ & $(+v e)$ & $(-\mathrm{ve})$ & $(+\mathrm{ve})$ & $(-v e)$ & $(+v e)$ & (-ve) \\
\hline & 37 & 113 & 40 & 110 & 42 & 108 & 47 & 103 & 49 & 101 \\
\hline Total & \multicolumn{2}{|c|}{150} & \multicolumn{2}{|c|}{150} & \multicolumn{2}{|c|}{150} & \multicolumn{2}{|c|}{150} & \multicolumn{2}{|c|}{150} \\
\hline
\end{tabular}

Table (3): Relative Sensitivity and specificity of RBT, STAT, ELISA and Superagglutination test for diagnosis of bovine brucellosis

\begin{tabular}{|lccccccc|}
\hline Tests & & & & & & True & False- \\
& Sensitivity & Relative & Specificity & True positive & False- & negative & negative \\
& & sensitivity & & predictive & positive & predictive & \\
\hline RBPT & $24.66 \%$ & $75.51 \%$ & $100 \%$ & $100 \%$ & Zero & $89.38 \%$ & $24.49 \%$ \\
\hline STAT & $26.66 \%$ & $81.63 \%$ & $100 \%$ & $100 \%$ & Zero & $91.82 \%$ & $18.37 \%$ \\
\hline ELISA & $28 \%$ & $85.71 \%$ & $100 \%$ & $100 \%$ & Zero & $93.52 \%$ & $98.16 \%$ \\
\hline Superagglutinationn & $31.33 \%$ & $95.92 \%$ & $100 \%$ & $100 \%$ & Zero & $98.06 \%$ & $4.08 \%$ \\
& & & & & & & \\
\hline
\end{tabular}


Lamees A. El-Tantawy et al......

Table 4: Results of RBT, STAT, ELISA and Superagglutination test against CFT

\begin{tabular}{|c|c|c|c|c|}
\hline \multicolumn{4}{|c|}{ Test } & \multirow[t]{2}{*}{$\begin{array}{c}\text { CFT } \\
\text { Gold Standard Test }\end{array}$} \\
\hline \multirow{2}{*}{ RBPT } & Positive & 37 & 0 & \\
\hline & Negative & 12 & 101 & \multirow{7}{*}{$\begin{array}{c}49 \text { sample were positive } \\
101 \text { samples were } \\
\text { negative }\end{array}$} \\
\hline \multirow{2}{*}{ STAT } & Positive & 40 & 0 & \\
\hline & Negative & 9 & 101 & \\
\hline \multirow{2}{*}{ ELISA } & Positive & 42 & 0 & \\
\hline & Negative & 7 & 101 & \\
\hline \multirow{2}{*}{$\begin{array}{l}\text { Superagglutination } \\
\text { test }\end{array}$} & Positive & 47 & 0 & \\
\hline & Negative & 2 & 101 & \\
\hline
\end{tabular}

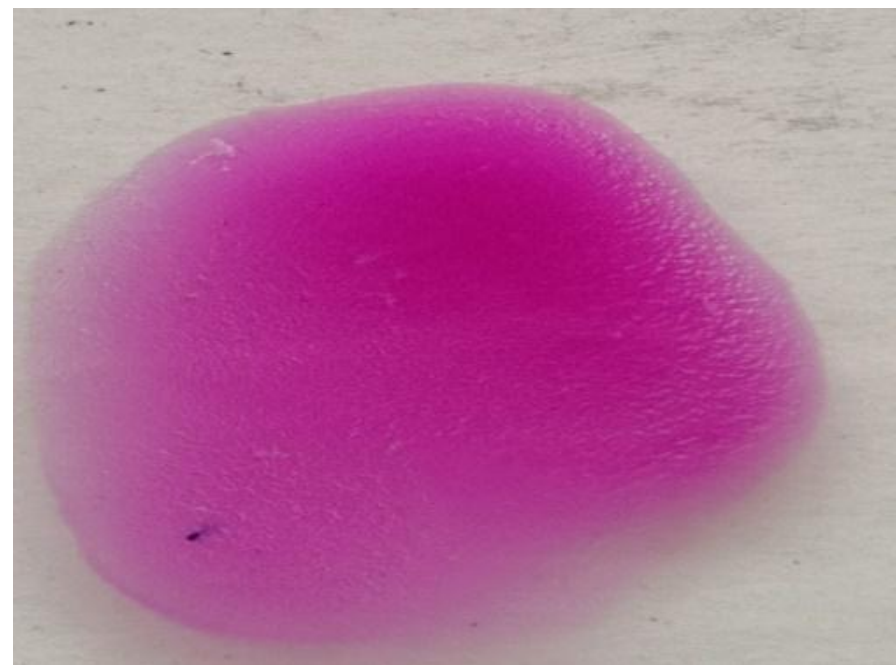

Fig.1: Macroscopic view of the slide in positive

\section{RBPT}

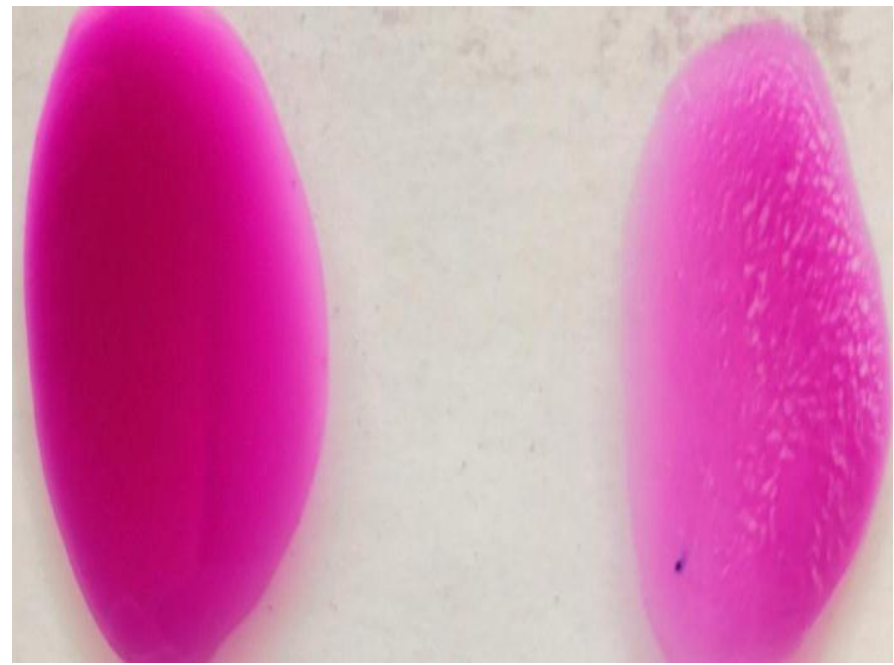

Fig.2: Macroscopic view of the slide in positive and negative RBPT. 


\section{Effects of Chemically Pretreated Bovine Serum Samples on Sensitivity}

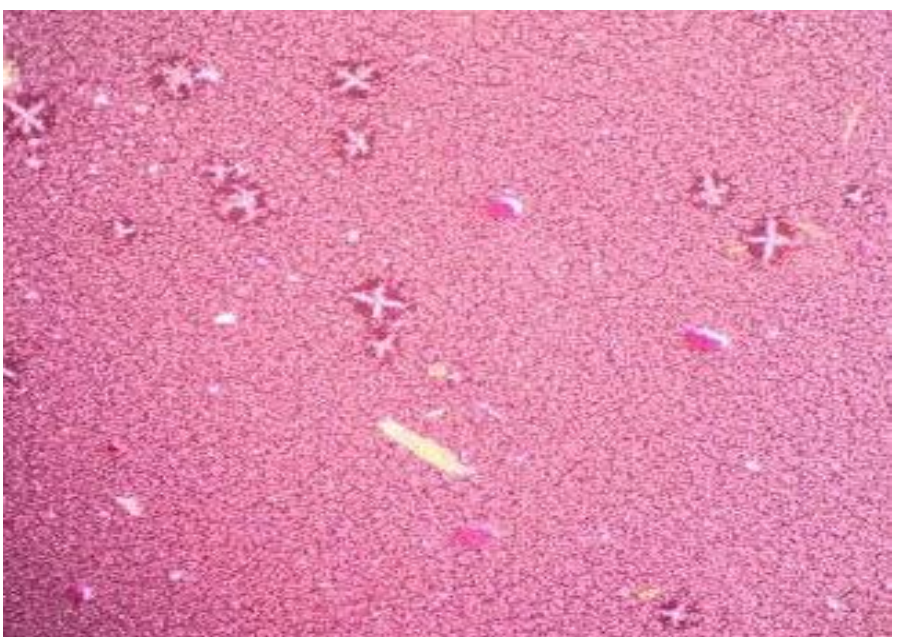

Fig.3: Microscopic view of the slide (low power) in negative RBPT.

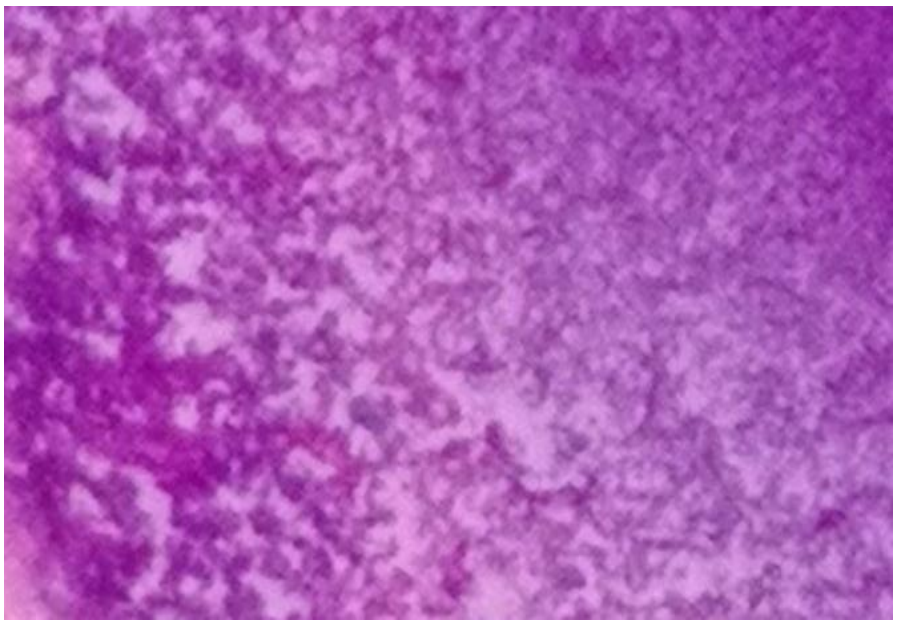

Fig.5: Macroscopic view of the slide in positive Superagglutination test.

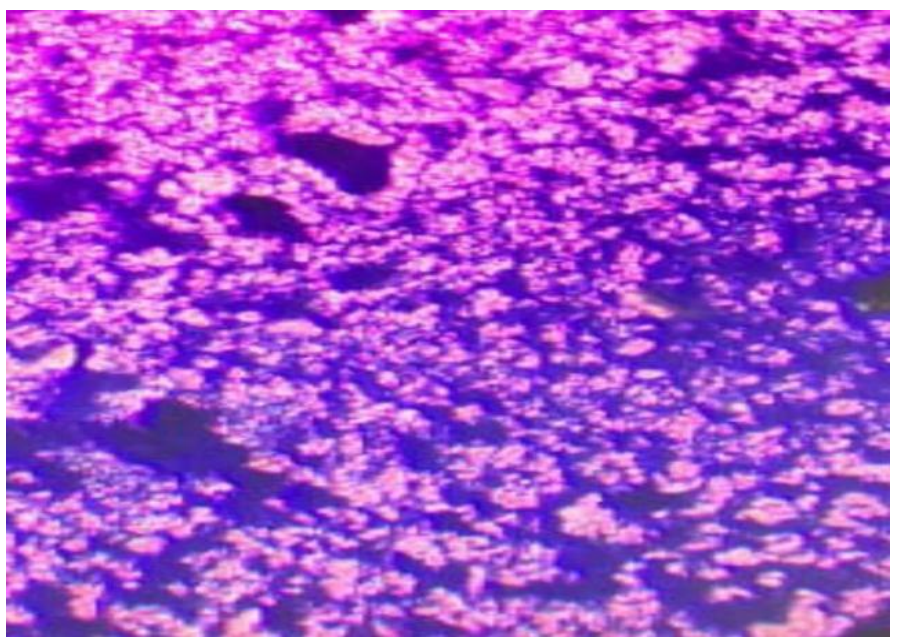

Fig7: Microscopic view of the slide (low power) in positive Superagglutination test.

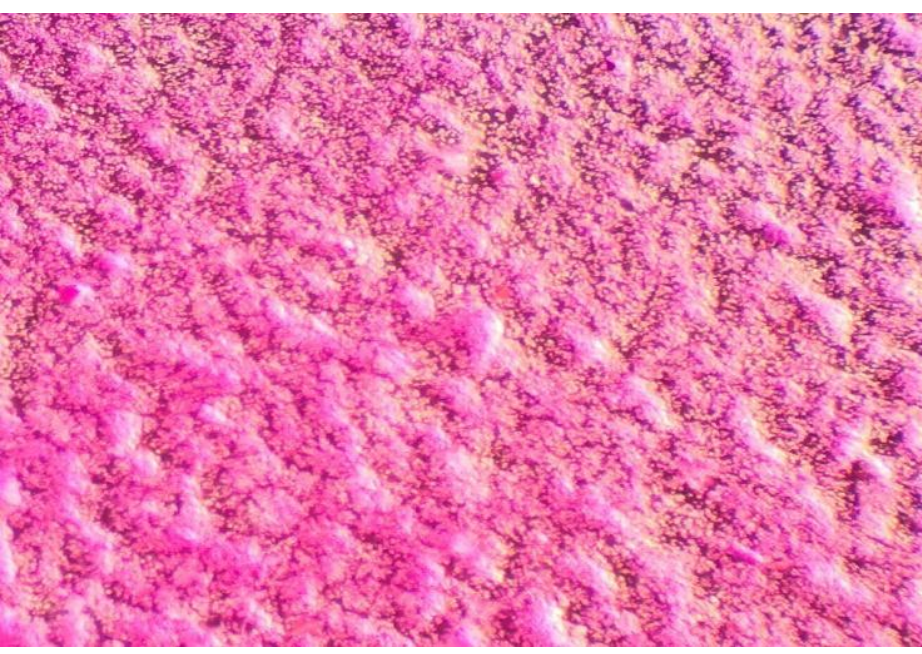

Fig.4: Microscopic view of the slide (low power) in positive RBPT.

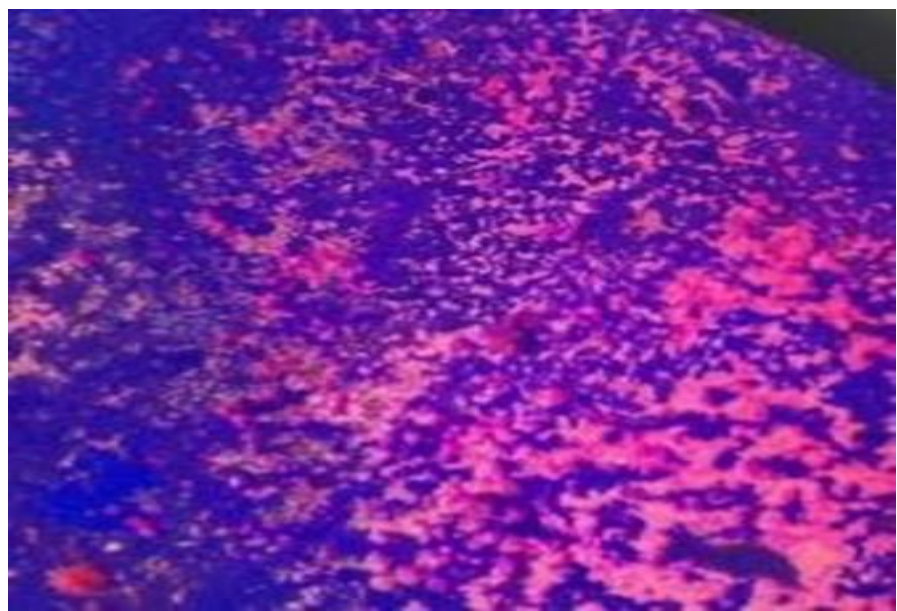

Fig.6: Microscopic view of the slide (low power) in positive Superagglutination test.

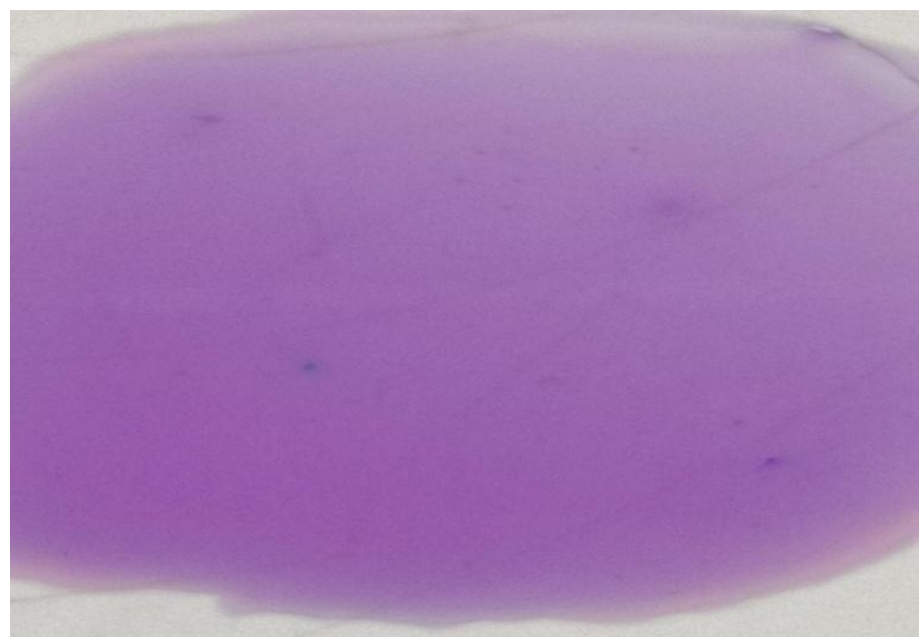

Fig.8: Macroscopic view of the slide in the negative Superagglutination test. 
Lamees A. El-Tantawy et al......

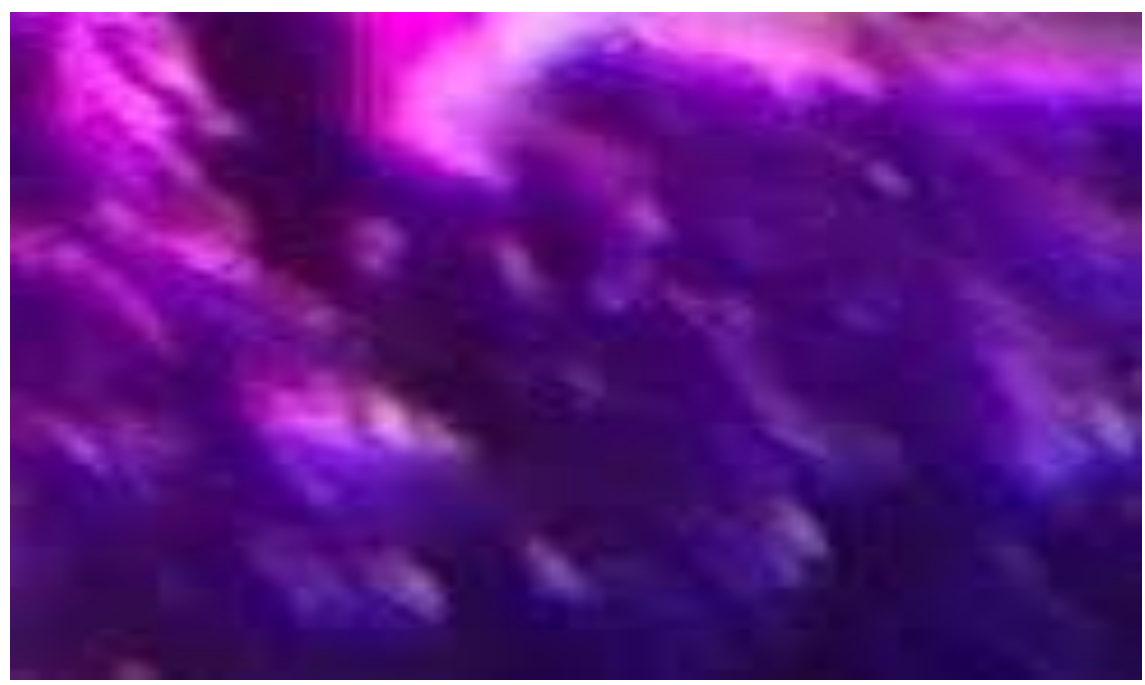

Fig.9: Microscopic view of the slide (low power) in negative Superagglutination test.

\section{DISCUSSION}

Brucellosis is an important and widely prevalent zoonotic disease of human and animals caused by Brucella species (OIE, 2016). The most common, screening and rapid serological test used for the diagnosis of brucellosis is Rose Bengal plate test (RBPT) (Novita, 2017) which based on the agglutination of antigen (killed Brucella abortus S99) by the antibodies present in animals sera. Although it is a cheap, simple and effective test and it can be carried out with the minimum of equipment, and the result is read by the naked eye, the RBPT is generally considered to be less sensitive than other serological tests like standard tube agglutination test, complement fixation test (CFT) and ELISA (Chachra et al.,2009). Generally, the negative results given by RBPT and STAT when used alone need to be further confirmed by other tests like CFT and ELISA, to avoid any possibility of false diagnosis of brucellosis (Raies $\boldsymbol{e t}$ al., 2013).

This study aimed to minimize false-negative results of RBPT during the screening of bovine brucellosis and overcome the prozone phenomena. Three simple steps were developed to overcome this problem. The first step was the addition of Coomassie blue which is a protein stain of contrasting color, when serum sample mixed with its serum antibodies stained blue. Then adding of biotinylated anti-bovine IgG and streptavidin to enhance the clump size by cross-linking the antibodies molecules making larger and more compact mass of clumps; it makes the clumps 4 times larger and compact. So, the Superagglutination test detected more positive samples than other serological tests, it identified all the sera giving false-negative results as well as sera giving false-positive results by
RBPT, STAT and ELISA. It could detect all the positive samples that were undetected by the other tests. The new Superagglutination test and common serological tests i.e.RBPT, STAT, ELISA and CFT were applied on all 150 serum samples. (Table 2).

Formation of clear agglutination of both blue and pink color together could be considered as positive in case of Superagglutination test ( figure 5,6,7 ), while the absence of clear agglutination and aggregation of pink color alone or blue-colored mass alone were considered as negative (figure 8,9).

The Superagglutination test gave superior results in detecting anti-brucella antibodies compared to the conventional rose bengal plate test (Abou-Chaker et al., 2009) which showed nonspecific one colored aggregates by the naked eye (figure 1,2 ) and under low power of light microscope as in figure ( 3,4 ). Complement fixation tests were considered as a gold standard test to determine the sensitivity and specificity of tested antigens in absence of bacteriological isolation (Yohannes et al., 2012) Statistics in this study were considered the $95 \%$ confidence intervals $(95 \% \mathrm{CI})$.

Concerning CFT as a gold standard test, results of this study was in agreement with Tsai et al., (1991); Magnarelli et al.,(1991); Chang, et al., (1993); Hu et al., (2014); Saxena et al., (2013 and 2015) in terms of that Superagglutination test showed the highest sensitivity when compared with other tests performed in this study which was (95.92\%)This may be due to the lesser number of false-negative results obtained with Super agglutination test (4.08\%) compared to the other tests as 2 samples only were negative by modified Rose Bengal antigen out of 49 sample(table 3). Whereas, there were 12,9 and 7 negative samples 


\section{Effects of Chemically Pretreated Bovine Serum Samples on Sensitivity ......}

of brucellosis sera with traditional Rose Bengal test, STAT and ELISA tests respectively (table 4).

\section{CONCLUSION}

In Superagglutination test detected more positive samples than other serological tests, it could identify all the sera giving false-negative results as well as sera giving false-positive results by RBPT, STAT and ELISA.It could detect all the positive samples that were undetected by the other tests.Superagglutination test is simple and significantly enhance the sensitivity of the agglutination test.The Results of this study recommended the use of Superagglutination test as a good diagnostic and confirmatory test to be used for diagnosis of bovine brucellosis but more studies are needed to be done on large cattle populations accompanied with bacteriological isolation to detect the sensitivity and specificity of this test and also to validate it.

\section{REFERENCES}

ABOU CHAKER, K., MEYER, O., \& SALAMA, A. 2009. Rapid typing of the human neutrophil antigen 1a by the particle gel agglutination assay. Tissue antigens, 73(3), 242-244.

ALTON, G.G., JONES, L.M., ANGUS, R.D. AND VERGER, J.M. 1988. Techniques for the Brucellosis Laboratory; Institutional de la Recherche Agronomique: Paris, France, pp. 17-62.

AUSTRALIAN BUREAU OF ANIMAL HEALTH, 1979. Standard definition and rules. In: Bovine brucellosis and tuberculosis national eradication campaign, Australian Bureau of Animal Health, Canberra, Australia, 1: 1-9.

CHACHRA, D., SAXENA H.M., KAUR, G., CHANDRA M. 2009. Comparative efficacy of Rose Bengal plate test, standard tube agglutination test and Dot ELISA in immunological detection of antibodies to Brucella abortus in sera. J. Bacteriology Research. 1(3):30-33

CHANG, Y. H., \& FOEGEDING, P. M. 1993. Biotin Avidin Enzyme- Linked Immunosorbent Assay For Bacillus Spores In Buffer And Food 1. Journal of Rapid Methods \& Automation in Microbiology, 2(3), 219-227.

HU, C., DOU, W., \& ZHAO, G. 2014. Enzyme immunosensor based on gold nanoparticles electroposition and Streptavidin-biotin system for detection of $\mathrm{S}$. pullorum \& $\mathrm{S}$. gallinarum. Electrochimica Acta, 117, 239-245.

MAGNARELLI, L. A., \& ANDERSON, J. F. 1991. Adsorption and biotin-streptavidin amplification in serologic tests for diagnosis of Lyme borreliosis. Journal of clinical microbiology, 29(9), 1761-1764.

MALIK, R., GUPTA, M.P., SIDHU, P.K., FILIA, G., SAXENA, H.M. AND SHAFI, T.A. 2013. Comparative evaluation of indirect enzyme-linked immunosorbent assay, Rose Bengal plate test, microagglutination test, and polymerase chain reaction for diagnosis of brucellosis in buffaloes. Turk. J. Vet. Anim. Sci. 37:1-5.

NOVITA, R. 2017. Rose Bengal Test and Complement Fixation Test To Detect Human Brucellosis In Occupationally Exposed Groups At Cilawu District, Garut. In 1st International Conference in One Health (ICOH 2017). Atlantis Press.

O.I.E. 2016. Manual of Diagnostic Tests and Vaccines for Terrestrial Animals. Chapter 2.1.4. Brucellosis, Office International des Epizooties, Paris.

RAIES UL ISLAM M, GUPTA MP, SIDHU PK, FILIA G, SAXENA HM, SHAFI TA. 2013. Comparative evaluation of indirect enzyme-linked immunosorbent assay, Rose Bengal plate test, microagglutination test, and polymerase chain reaction for diagnosis of brucellosis in buffaloes. Turk J Vet Anim Sci.37:1-5.

SAXENA, H.M. AND KAUR, P. 2013. A new Superagglutination test to minimize false-negative and false-positive results common with plate/slide agglutination tests for the diagnosis of infectious disease.Int.J.Trop.Health, 3:199-209.

SAXENA, H.M., CHOTHE, S., AND KAUR, P. 2015. Simple solutions to false results with plate /slide agglutination tests in the diagnosis of infectious diseases of man and animals.MethodsX, 2,345-352.

TSAI, H. J., \& SAIF, Y. M. 1991. Detection of antibodies against Bordetella avium in turkeys by avidin-biotin enhancement of the enzyme-linked immunosorbent assay and the dot-immunobinding assay. Avian diseases, 801-808.

WHO,2006. Brucellosis in humans and animals.WHO/CDS/EPR/2006.7

YOHANNES, M., GILL J.P.S., GHATAK S., SINGH D.K. AND TOLOSA T. 2012. Comparative evaluation of the Rose Bengal plate test, standard tube agglutination test and complement fixation test for the diagnosis of human brucellosis. Rev. sci. tech. Off. int. Epiz, 31 (3), 979-984.

How to cite this article:

Lamees A. El-Tantawy, Lubna, F. Farahat, Eman S. Ramadan, and Fatma F. Warda.2020. Effects Of Chemically Pretreated Bovine Serum Samples On Sensitivity Of Rose Bengal Test For Serodiagnosis Of Bovine Brucellosis. Journal of Applied Veterinary Sciences, 5(2): 6-12. 